\title{
Correction to: Tet3 regulates cellular identity and DNA methylation in neural progenitor cells
}

\author{
Mafalda Santiago ${ }^{1,2} \cdot$ Claudia Antunes $^{1,2} \cdot$ Marta Guedes $^{1,2} \cdot$ Michelina lacovino $^{3,9} \cdot$ Michael Kyba $^{3} \cdot$ Wolf Reik $^{4,5}$. \\ Nuno Sousa ${ }^{1,2} \cdot$ Luísa Pinto $^{1,2} \cdot$ Miguel R. Branco $^{6} \cdot$ C. Joana Marques ${ }^{1,2,7,8}$
}

Published online: 9 January 2020

(c) The Author(s) 2020

\section{Correction to: Cellular and Molecular Life Sciences https://doi.org/10.1007/s00018-019-03335-7}

The article Tet3 regulates cellular identity and DNA methylation in neural progenitor cells, written by Miguel R. Branco and C. Joana Marques, was originally published electronically on the publisher's internet portal (currently SpringerLink) on 23 October 2019 without open access. With the author(s)' decision to opt for open choice, the copyright of the article changed on 29 December 2019 to $($ ) The Author(s) 2019 and the article is forthwith distributed under the terms of the Creative Commons Attribution 4.0 International License (http://creativecommons.org/licenses/ by/4.0/), which permits use, duplication, adaptation, distribution and reproduction in any medium or format, as long as you give appropriate credit to the original author(s) and the source, provide a link to the Creative Commons license and indicate whether changes were made. The original article has been corrected.

Open Access This article is licensed under a Creative Commons Attribution-NonCommercial 4.0 International License, which permits any non-commercial use, sharing, adaptation, distribution and reproduction

The original article can be found online at https://doi.org/10.1007/ s00018-019-03335-7.

Miguel R. Branco

m.branco@qmul.ac.uk

$\bowtie$ C. Joana Marques

cmarques@med.up.pt

1 Life and Health Sciences Research Institute (ICVS), School of Medicine, University of Minho, 4710-057 Braga, Portugal

2 ICVS/3B's-PT Government Associate Laboratory, 4710-057 Braga/Guimarães, Portugal

3 Lillehei Heart Institute and Department of Pediatrics, University of Minnesota, Minneapolis, MN 55455, USA

4 Epigenetics Programme, The Babraham Institute, Cambridge CB22 3AT, UK in any medium or format, as long as you give appropriate credit to the original author(s) and the source, provide a link to the Creative Commons licence, and indicate if changes were made. The images or other third party material in this article are included in the article's Creative Commons licence, unless indicated otherwise in a credit line to the material. If material is not included in the article's Creative Commons licence and your intended use is not permitted by statutory regulation or exceeds the permitted use, you will need to obtain permission directly from the copyright holder. To view a copy of this licence, visit http://creativecommons.org/licenses/by-nc/4.0/.

Publisher's Note Springer Nature remains neutral with regard to jurisdictional claims in published maps and institutional affiliations.

5 The Wellcome Trust Sanger Institute, Cambridge CB10 1SA, UK

6 Blizard Institute, Barts and The London School of Medicine and Dentistry, Queen Mary University of London, London E1 2AT, UK

7 Department of Genetics, Faculty of Medicine, University of Porto, 4200-319 Porto, Portugal

8 i3S-Instituto de Investigação e Inovação em Saúde, Universidade do Porto, 4200-135 Porto, Portugal

9 Present Address: Division of Medical Genetics, Department of Pediatrics, Harbor UCLA Medical Center, Los Angeles Biomedical Research Institute, Torrance, CA 90502, USA 